\title{
Differentiated Learning by Using Innovation and Engineering Technology
}

\author{
Hamdia Hmmad Alyazeedi \\ Southern Connecticut State University, New Haven, CT USA
}

\begin{abstract}
Teaching the students to have a deeper understanding of the concepts will also (if your district allows) let you explore the concepts as a class in a variety of ways, which will help with the students of varying learning styles. Once you follow through with the steps of the backwards design approach you will be more prepared as the educator who will give your students a more effective teaching and learning experience. Classroom management is another important concept for me as teacher. Establish effective class rules will help me to discipline students learning and behaviours.
\end{abstract}

Keywords: Differentiated, Innovation, Technology, Intelligences.

\section{INTRODUCTION}

In differentiation class, the management is very important to different student talents and learning styles. In the part. Teacher should consider about it; many teachers don't aforementioned vignette, a good strategy Mr. Jones could have a clear picture about it. Thus, management class use would be to differentiate math instruction in a way to includes materials, resources, instruction time and engage Steve and keep him from daydreaming or student's behaviour, they are complex and linked to misbehaving. This form of teaching is designed to meet gathering, therefore, any trouble in one of these can impact the needs of diverse learners and emphasizes student on the classroom management. Differentiation of responsibility, peer tutoring, flexible grouping, and student management classroom required many criterions that choice (Grimes and Stevens 2009). Single is a very teacher should be aware about it. Sharing students and effective strategy to manage or create routine in the class. modifying classroom management are strength points to Teacher can use fingers, count or raise the hand instead achieve diversity in the classroom. Teacher should variable with students to pay attention or stop doing some establish a good routine to keep student's learning and things. Clap hand, light off of overhead also are examples behaviour. Building welcoming community is effective to about a good signal that would help teachers to discipline establish opining class members. So, the way to build it students talking. Clear directions. An excellent classroom effectively is getting students trust and love. Give students management includes clear direction, which would help time to speak free about what they need is an excellent the students remind and understand what teacher gives idea for teachers. Establish routine for meeting with them, using the recorder, Task card are another strategy students every morning also is great step to create strength that aids students to understand the direction and would be relationship with students [1].

The common steps to create effective classroom management know your students first, the more successful teacher the more she/he knows students' needs, style learning, interest and what can success or difficult learning. Collaborate with students to build guideline for classroom management or routine can be successful for differentiation class and this could pass massage to students whom they work as one a team.

Many teachers have frequently neglected the talents of the most creative individuals, leading these individuals to unpleasant experiences similar to what Steve experienced in Mr. Jones's class. Keefe (2007) discusses how some of the world's most talented people, including Charles Darwin, Patrick Henry, Sir Isaac Newton, Louis Pasteur, Madame Curie, Orville Wright, Albert Einstein, and Marlon Brando, were encouraged to leave school as a result of their alleged inability to learn. Had their teachers respected the idea that different pupils learn in different ways and had they differentiated instruction according to their students' needs and talents, they probably would have recognized these students as gifted. Differentiated instruction is a way of recognizing and teaching according

\section{INTELLIGENCES ANDDIFFERENTIATED INSTRUCTION}

Differentiated instruction is based on Howard Gardner's theory that students learn through various intelligences (Kapusnick and Hauslein 2001). Gardner (1983) first identified the following intelligences in his book Frames of Mind: logical/mathematical, verbal/linguistic, musical, visual/spatial, bodily/kinesthetic, interpersonal, and intrapersonal. He later added the naturalist intelligence (Checkley 1997).differentiation is recognized to be a compilation of many theories and practices. Based on this review of the literature of differentiated instruction, the "package" itself is lacking empirical validation. There is an acknowledged and decided gap in the literature in this area and future research is warranted [4].

According to the proponents of differentiation, the principles and guidelines are rooted in years of educational theory and research. For example, differentiated instruction adopts the concept of "readiness". That is the difficulty of skills taught should be slightly in advance of the child's current level of mastery. This is grounded in 
the work of Lev Vygotsky (1978), and the zone of scoring sheet; this activity could support differentiation proximal development (ZPD), the range at which learning learning in the classroom. takes place. The classroom research by Fisher at al.(1980), strongly supports the ZPD concept figure 1. The researchers found that in classrooms where individuals were performing at a level of about $80 \%$ accuracy, students learned more and felt better about themselves and the subject area under study (Fisher, 1980 in Tomlinson, 2000). Other practices noted as central to differentiation have been validated in the effective teaching research conducted from the mid 1980's to the present. These practices include effective management procedures, grouping students for instruction, and engaging learners (Ellis and Worthington, 1994).

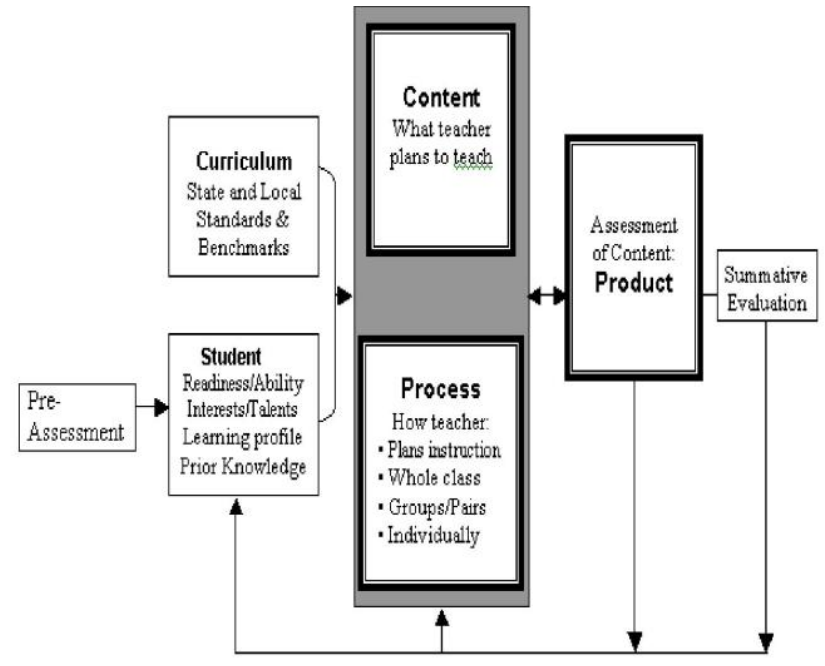

Figure 1: Learning Cycle and Decision Factors

\section{LINGUISTIC LEARNERS}

Linguistic learners are characterized as students with excellent written and oral skills. They excel in the humanities and focus on careers in journalism and politics. Instructional Strategies that work for linguistic learners must focus on self-expression. Using the Internet for research and then presenting their findings is an excellent project for these students. They are very comfortable speaking and benefit greatly presentations or from giving doing desktop publishing (Carlson Pickering 1999; Lamb 2004h). Students with a strong linguistic intelligence enjoy a project such as a class poem.

The teacher sets computers to act as learning stations. Each computer has an up a few open word processing document with lines that are incomplete (e.g., "I am," "I see," "I think"). Students then move to each station and complete the phrase with a statement of their choosing. Linguistic learners embrace this learning opportunity because they can use their verbal skills to express an abstract concept (Haywood n.d.).

\section{ANCHOR ACTIVITY}

It is a good idea for students whom finish works early. Teacher would appliance it correctly. Anchor could be books - activities meeting the curriculum needs- teacher should provide students feedback, self-checking rubric or
Making smooth routine and procedures in a classroom many ahead in the classroom is important to organize it because the appearing of the class is significant factor for discipline students. The important preparation teacher should eager about It include: 1- Resources area 2. File for rubric 3-Create student's office area. 4-Arrange furniture in the class room that can help a teacher, and students feel comfortable 5- create a proper traffic path for students 6 create a place for display area. The fixable class room space helps teachers and students to keep classroom organize that could reflect on student's behaviour, Teacher would encourage students to help other in an arrangement classroom.

This is interesting and essential question to identify the ideals and problems associated with the RTI process in our schools. I found it very interesting in the "Wrong Questions; How do we raise our test scores?" section, where the authors discussed the standards assessed on the standardized assessments in relation to what is taught in the classroom. If the curriculums and standardized assessments were directly related, then the test scores would correlate more accurately to the RTI program. However, currently the tests are asking students a rage of questions that are not directly addressed in classroom instruction and do not necessarily show the students true skills that will help them be successful in their future endeavours. I also found it interesting under the "What's wrong with this kid?" sections discussing the struggling students were generally thought to have a disability rather than, there was something wrong with the way of teaching. Students are then subjected to a number of assessments that do not indicate how affective the teaching truly is rather than identifying students who are struggling as special-education students, revising how we teach the students may be a much more successful step rather than pushing these struggling students into special-education testing, which may not truly give the student what they need to be successful [4].

There is a very clear and concise step by step process to identifying students who are at risk of "poor learning outcomes." The preliminary assessments followed the more in depth assessments will truly give the teachers more information on how to group the students as well as where to be with the groups. In most cases if one student is struggling with a topic the other students are as well. It is also extremely important to make sure the interventions are evidence based and proved to show success. This will best fit the groups' needs, there will be adequate progress monitoring during the interventions to gauge how the students are doing. If students are continuing to struggle, then the teacher must decide if there needs to be a change in intervention or if the student needs further assistance, such a special-education referral.

\section{IMPLEMENT TECHNOLOGY IN THE CLASS}

I management by using technology is very important, especially at this time, many devices became part of student's life, Effective classroom management can get 
benefits from these devices by implementation it in the right way during classroom instead students talking; they can use it to write. Curriculum is parted from classroom management, providing the students with high quality of curriculum could help students to accomplish the goals of content and engage in the class. Workstation, using cyber station and Partnerships are strategies support good management in the classroom. Clock buddies It is great idea to achieve the differentiation instruction during learning with a group, and this strategy gives students opportunity for choice; students work with own clock buddies. This idea design by dividing work in the group through many areas includes readiness, references and random buddies.

Although most teachers today are quick to recognize the importance of using technology in their classrooms (Roblyer, 1993), numerous barriers can block implementation efforts. These barriers range from personal fears (What will I do if the technology fails and my lesson can't proceed? How will I gain the confidence I need?) to technical and logistical issues (How does this software package work? Where or when should I use computers?) To organizational and pedagogical concerns (How can I ensure that students obtain adequate computer time without missing other important content? How do I weave computers into current curricular demands?). Although teachers may not face all of these barriers, the literature suggests that anyone of these barriers alone can significantly impede meaningful classroom use (Hadley \& Sheingold, 1993; Hannafin \& Savenye, 1993; Hativa \& Lesgold, 1996). assessment in kindergarten science. Teaching Science, 54(2), 50-53. SMART Boards are revolutionizing classrooms and have undoubtedly become the signpost of technology- rich learning environments. SMART Boards allow teachers to teach and share information with students in a multiplicity of ways [5].

Presenting a compelling case for the usage of SMART Board for teaching Science at primary school level, backed by research at Abbot sleigh Junior School, the authors begin the article highlighting the specific challenges encountered in teaching science to primary school students and assessing their understanding of the subject.

The authors take a step-by-step approach of demystifying the technology behind SMART Boards, then detailing the range of functions that can be carried out both by a teacher and a student using it and reasons out that SMART board technology, which was earlier confined to business or boardroom purposes has now become ubiquitous in the education sector, owing to the cost reduction in the technology.

The authors make a pertinent point that young students are highly motivated when content is presented in an engaging and a collaborative learning environment on a SMART Board. This ensures sustained attention and reinforces the key ideas or concepts [2].

The specific stages or steps in the teaching/ learning process, where SMART Boards have enriched the experience have been clearly illustrated with the help of practical examples, for instance, lesson introductions, making predictions, building up instructions for practical tasks, recording results, reinforcement of key ideas, concluding lessons and most importantly, assessment, to show the young learners' understanding of concepts without the need for highly developed reading and writing skills.

\section{CONCLUSION}

In a classroom, I think revising the teaching style would be helpful to manage the curriculum and the motivation of the students. If there were struggling students in the classroom, rather than sending the students to specialeducation testing, I would look into different ways to teach the subject to the students. If the student learns in a different way, then I would create different lessons, manipulative, or activities to help the student better understand the subject. After trying multiple approaches if the student still continues to struggle, then would be the time to refer to special-education testing. In my classroom, I would have identified the students who are struggling and are in need of additional help. I believe although it may seem like a lot of assessments, it will truly help the teacher identify the best practices and effective teaching methods for those struggling students. Using evidence based intervention will best help the students, they will be using interventions that have proven to touch upon the areas in which those students are struggling. In my classroom, I think this would be a great way to approach teaching the curriculum. It would not only give me a deeper insight into the knowledge, skills, and tools that my students need to have to be successful in that unit of study in addition to further studies; it will also allow me to better understand what information the students have and how it can aid them in the curriculum.

\section{REFERENCES}

[1] Simpson, C., Thomas, C., Findlay, K., Bayer, E., \& Maule, A. J. (2009). An Arabidopsis GPI-anchor plasmodesmal neck protein with callose binding activity and potential to regulate cell-to-cell trafficking. The Plant Cell, 21(2), 581-594.

[2] Screaton, R. A., DeMarte, L., Dráber, P., \& Stanners, C. P. (2000). The specificity for the differentiation blocking activity of carcinoembryonic antigen resides in its glycophosphatidyl-inositol anchor. The Journal of cell biology, 150(3), 613-626.

[3] Moore, B. V. (1921). Personnel selection of graduate engineers: The differentiation of apprentice engineers for training as salesmen, designers, and executives of production. Psychological Monographs, 30(5), i.

[4] Weinstein, R. S., Gregory, A., \& Strambler, M. J. (2004). Intractable self-fulfilling prophecies fifty years after Brown v. Board of Education. American Psychologist, 59(6), 511.

[5] Baum, S. M., Cooper, C. R., \& Neu, T. W. (2001). Dual differentiation: An approach for meeting the curricular needs of gifted students with learning disabilities. Psychology in the Schools, 38(5), 477-490. 